Two particularly interesting tables from the University Grants Committee itself set out staff/student ratios on two different bases for each university, except Oxford and Cambridge, and university recurrent costs per student; while a note from the University of Kent instances losses of efficiency through inability to commit capital except at short range. It may be noted here that the Estimates Committee thought that it was time for the Vice-Chancellors' Committee to become more effectively representative, and that there was room for more intimate co-operation between the universities and the regional economic councils which have recently been set up. It also thought that the colleges of advanced technology might be unduly optimistic as to their prospects in the larger world of university finance, and was concerned that these colleges as a whole possessed no cushion against financial rigours such as the newly founded universities possessed in their large appeals. The Estimates Committee was critical of the lengthy process of negotiation between the Ministry of Health, the Department of Education and Science and the University Grants Committee involved in the development of medical schools and would welcome a simplification of the present procedure.

\section{Production of Phosphorus and its Compounds in Canada}

THE largest subsidiary overseas of the well-known Albright and Wilson Chemical Group of the United Kingdom is the Electric Reduction Company of Canada, Ltd., the main interest of which is in the manufacture of phosphorus, phosphoric acid, industrial and agricultural phosphates, and chlorates. 'ERCO', as it is known, operates in four factories: at Buckingham and Varennes, Quebec; at Port Maitland, Ontario; at Vancouver, British Columbia; and maintains its research laboratories and executive offices in Toronto, Ontario. A newly-issued and copiously illustrated brochure entitled Erco Today vividly tells the growth story of this chemical manufacturing company and of its place as a supplier of these products to world markets (Pp. 48. Toronto: Electric Reduction Company of Canada, Ltd., 1965). The functions of each main plant and the processes involved are clearly described. At Varennes the primary concern is elemental phosphorus; the source is phosphate rock from Florida, whence it is shipped in 20,000-ton cargoes up the Atlantic seaboard and by way of the St. Lawrence Seaway to a wharf near the plant. Each shipload is unloaded and transported to the Varennes stock-piles within $30 \mathrm{~h}$ to cope with the daily capacity of two giant electric furnaces (more than 750 tons) to which are fed precisely sized and mixed quantities of coke, silica, and phosphate rock (tri-calcium phosphate) every $24 \mathrm{~h}$. "Inside the steelclad, carbon-walled furnaces, 35,000 kilowatts of Quebec's abundant hydro-electric power flow through huge carbonbased electrodes to convert these raw materials into more than 20,000 tons of yellow, wax-like elemental phosphorus each year." From Varennes phosphorus in water is transported to the Buckingham plant for further processing. Fundamental at Buckingham is the production of phosphoric acid; much of this is reacted with sodium carbonate or hydroxide to form eight different kinds of soda phosphate; some, with lime, goes to manufacture of mono-calcium phosphate, also, with appropriate chemicals, to organic phosphates; Buckingham also produces red amorphous phosphorus and phosphorus sesquioxide used in the match industry. Products of the Chlorate and Agricultural Chemicals Divisions are described; the role of the latest Port Maitland plant in manufacture of superphosphates and phosphatic fertilizers is particularly impressive.

\section{World-wide Radio Noise Measurements}

Since July 1957, measurements of the level of atmospheric noise received on eight radio frequencies between
0.013 and $20 \mathrm{Mc} / \mathrm{s}$ have been made at eighteen stations throughout the world in a co-operative programme coordinated by the U.S. National Bureau of Standards. The results of these measurements are published in a series of Technical Notes entitled Quarterly Radio Noise Data, the latest of which is No. 18-21 (Pp. vi+93. Washington, D.C.: Government Printing Office, 1965. 50 cents). This tabulates the results obtained during the three-month period December 1964-February 1965. These Technical Notes are prepared by W. Q. Crichlow, R. T. Disney and M. A. Jenkins of the Central Radio Propagation Laboratory, Boulder, Colorado. The present publication contains photographs of the standard type of atmospheric radio noise recorder and of the aerial system used at all the stations. An accompanying map shows the distribution of the 17 land stations, and a typical position of the floating Antarctic research vessel, U.S.N.S. Eltanin, which operates as a mobile station in the South Pacific. Following an introductory description of the evaluation of the three basic parameters of the noise-mean power, mean envelope voltage and mean logarithm of the envelope voltage - the values measured at every hour of each day during the three-month period are tabulated. A separate set of tables summarizes the observed values of radio noise for each of the frequencies and in 4-h time blocks throughout the three-month period, in accordance with the provisions of Report No. 322 of the International Radio Consultative Committee (CCIR). The values presented in the tables reflect the actual measured values of radio noise. The only editing for man-made noise or other contamination of the records has been done by the station operators, and no statistical study has been made in order not to delay the dissemination of the data in their present preliminary form. A short bibliography is attached to the report. This refers not only to individual scientific papers, but also to the publications of the CCIR and of the International Scientific Radio Union.

\section{Advance in Knowledge of a Fossil Fern}

Almost a century ago, Carruthers described a British Tertiary fern stem as Osmundites dowkeri; he realized it was like Osmunda but he felt he knew too little to identify it with Osmunda. Recently, the stems of the Recent Osmundacea have been investigated and we know how to distinguish the genera and even the sub-genera from a transverse section of the stem. Recently, also, a second British specimen was found, very carefully sectioned by the late W. N. Croft, and now described by Miss Marjorie E. J. Chandler (Bulletin of the British Museum (Natural History). Geology. Vol. 10, No. 6: The Generic Position of Osmundites dowkeri Carruthers. Pp. 139-161+12 plates. London: British Museum (Natural History), 1965. 42s.). She finds that it is a true Osmunda but belongs to the section Plenasium and not to the section which includes the British O. regalis. The ferns of Plenasium grow in South-east Asia. This then is another item in which our Eocene flora agreed with the living plants of Malaysia. It is interesting, too, that fragments of an Osmundaceous fern leaf from the British Tertiary $(O$. ligniticum) also probably belongs to the sub-genus Plenasium-perhaps the two kinds of fossil represent a single species.

\section{Soil Moisture}

Although an estimate of moisture content is one of the most common exercises in soil analysis, it is realized that the methods used have various disadvantages. A useful review, with a comprehensive bibliography, on "Measuring Soil Moisture", by F. Cope and E. S. Trickett, appears in Soils and Fertilizers $(28$, No. 3, 201; 1965). As in other analytical techniques, the sampling error imposes limits on the reliability and reproducibility of the results, and the need for a quick and accurate method for measuring soil moisture in situ is emphasized. The authors deal with the estimation of the amount of soil moisture by 